\title{
Program Corporate Social Responsibility (CSR) Pada PT Indocement Tunggal Prakarsa Tbk.
}

\author{
Rully Rahmayani ${ }^{1}$ dan Hana Silvana ${ }^{2}$ \\ ${ }^{1,2}$ Universitas Pendidikan Indonesia
}

\begin{abstract}
ABSTRAK
Penelitian ini bertujuan untuk mendeskripsikan Program Corporate social responsibility (CSR) yang dilaksanakan oleh PT Indocement Tunggal Perkasa. Jenis penelitian yang digunakan yaitu explanatory research, dengan pendekatan kuantitatif. Sampel dari penelitian ini adalah penerima program Pendampingan Kelompok Batik Pewarna Alam Ciwaringin yang berjumlah 77 orang responden. Teknik pengambilan sampel dalam penelitian ini menggunakan teknik total sampling. Teknik pengumpulan data menggunakan kuesioner, wawancara, dan studi pustaka. Uji hipotesis yang digunakan adalah uji F-test. Hasil Penelitian menunjukkan bahwa program corporate social responsibility pada dimensi memperoleh skor rata-rata tertinggi yaitu directionary, hal tersebut menunjukan bahwa masyarakat mengganggap bahwa keberadaan perusahaan memberikan manfaat bagi mereka. Sedangkan dimensi yang memperoleh skor rata-rata terendah adalah personality yang berarti masyarakat belum memahami perusahaan seperti perusahaan dapat dipercaya. Maka dari itu, semakin baik program corporate social responsibility maka semakin baik pula citra perusahaan di masyarakat. oleh karena itu, Perusahaan diharapkan untuk terus mempertahankan program pendampingan kelompok batik pewarna alam Ciwaringin dan meningkatkan komunikasi kepada publiknya, sehingga upaya penyampaian program corporate social responsibility untuk membentuk citra positif perusahaan akan tercapai dengan baik. Sebagai dampak dari CSR yang dilakukan oleh perusahaan kegiatan ini mendapat respons yang positif dari masyarakat sekitar.
\end{abstract}

Kata-kata Kunci: Corporate social responsibility; pendampingan kelompok batik tulis pewarna alam ciwaringin cirebon; masyarakat; komunitas; citra perusahaan

\section{Coprporate Social Responsibility (CSR) Programs In PT Indocement Tunggal Prakarsa Tbk.}

\begin{abstract}
This study aims to describe the Corporate social responsibility (CSR) Program implemented by PT Incocement Tunggal Perkasa. Type of research used is explanatory research, with quantitative approach. Sample of this research is recipient of program of Guidance of Batik Coloring Group of Ciwaringin Natural which amounted to 77 respondents. Sampling technique in this research using technique of Total Sampling. Data collection techniques used questionnaires, interviews, and literature studies. Hypothesis test used is F-test. The results showed that the Corporate social responsibility program on the dimensions obtained the highest average score that is directionary, it shows that people assume that the existence of the company provide benefits for them. While the dimensions that get the lowest average score is the personality which means the public has not understood the company as a company can be trusted. Therefore, the better the Corporate social responsibility program the better the corporate image in the community. Therefore, the Company is expected to continue to maintain the Guidance program of Batik Colors Natural Coloring Ciwaringin and improve communication to the public, so that efforts to deliver CSR program to form a positive image of the company will be achieved well.
\end{abstract}

Keywords: Corporate social responsibility; batik group assistance write natural dye ciwaringin cirebon; public; community; coorporate image

Korespondensi: Hana Silvana, M.Si. Universitas Pendidikan Indonesia. Jl. Setia Budi Bandung. Email: hanasilva@upi.edu 


\section{PENDAHULUAN}

Seiring dengan perkembangan zaman semakin kompleks pula permasalahan yang terdapat dalam suatu perusahaan, dewasa ini perusahaan membutuhkan faktor lain guna mengukur pencapaian di samping faktor finansial. Tren dewasa ini perusahaan berlomba-lomba mendapatkan pemberitaan yang baik di media, hal tersebut semata-mata untuk mendapatkan citra positif, dan citra positif memberikan kesuksesan jangka panjang bagi perusahaan.

Beberapa manfaat mendapatkan citra yang positif bagi perusahaan antara lain daya saing jangka menengah dan panjang yang mantap (mid and long tern sustainable competitive position), menjadi perisai selama masa krisis (an insurance for adverse times), menjadi daya tarik eksekutif handal (attracting the best executives available), meningkatkan efektivitas strategi pemasaran (increasing the effectiveness of marketing instruments), penghematan operasional (cost savings) (Sutojo, 2004: 3). Oleh karena itu, sudah seharusnya perusahaan memantau segala pembentukan opini terkait perusahaan demi menjaga citra positif di masyarakat secara kontinu.

Meskipun tujuan utama berdirinya suatu perusahaan adalah untuk meraih keuntungan sebanyak-banyaknya, namun tidak dibenarkan jika perusahaan meraih keuntungan tersebut dengan mengorbankan kepentingan pihak lain yang terkait yakni para stakeholders. Hal ini sejalan dengan yang diungkapkan Holmes dalam jurnal yang ditulis Moir yang berjudul What Do We Mean By Corporate Social Responsibility (2001: 17) yang menemukan bahwa selain mencetak keuntungan, perusahaan juga harus membantu untuk memecahkan masalah sosial, atau perusahaan membantu untuk tidak membuat masalah. Karena hal ini memiliki potensi keuntungan baik jangka pendek maupun jangka panjang.

Indonesia Business Links (dalam Kartini, 2009: 2) menyatakan bahwa CSR adalah komitmen perusahaan untuk meminimalisir dampak negatif dengan memaksimalkan kontribusi positif kepada seluruh stakeholders dalam aspek ekonomi, sosial, dan lingkungan untuk memperoleh pembangunan berkelanjutan. Tindakan sekecil apapun yang dilakukan perusahaan akan sangat berarti bagi sosial masyarakat dan lingkungan sekitar perusahaan itu beroperasi. Pelaksanaan program CSR dapat dilaksanakan melalui beberapa kegiatan yang memberikan dampak positif bagi ekonomi, sosial dan lingkungan masyarakat di sekitar perusahaan.

PT Indocement Tunggal Prakarsa Tbk. merupakan perusahaan yang bergerak dalam 
bidang pertambangan batu kapur untuk memproduksi semen yang menerapkan program CSR. Salah satu program CSR tersebut adalah Program Batik Tulis Pewarna Alam Ciwaringin bertujuan sebagai sarana peningkatan kesehatan dan kesejahteraan pengrajin batik. Sentra pengembangan batik tulis pewarna khas Ciwaringin menerapkan sistem produksi bersih (clean production), ramah lingkungan, dan memperhatikan kesehatan dan keselamatan pengrajin dan pengelolaan limbahnya. Selain itu, program ini juga bertujuan untuk menghidupkan kembali sentra sebagai pusat pemasaran produk batik khas Ciwaringin yang representatif, menjadikan sentra sebagai tempat lahirnya pembatik-pembatik baru, dan berkontribusi mengurangi pengangguran.

Pada prinsipnya program ini di maksudkan untuk membangun "budaya mutu" dan kelompok usaha yang kuat dari dan oleh para pengrajin batik, dengan cara menghidupkan, membangun dan memperkuat modal sosial serta dilakukan fasilitasi, transfer ilmu, teknologi, dan pendampingan. Di samping itu juga Program Batik Tulis Pewarna Alam Ciwaringin merupakan sustainable development program. Programinidilakukan dengan cara mendampingi pengrajin selama lima tahun. Dampak yang dirasakan dari pelaksanaan program ini tidak hanya dirasakan saat program dilaksanakan, tetapi dapat dirasakan berkelanjutan oleh masyarakat.

Perusahaan ini merupakan perusahaan yang memproduksi semen dan saat ini merupakan salah satu produsen semen terbesar di Indonesia, dimana banyak materil tambang yang dapat menimbulkan dampak negatif bagi masyarakat maupun lingkungan sekitar. Industri bidang tambang perlu membangun citra perusahaan yang baik untuk meningkatkan kredibilitas dan daya saing perusahaan, dan juga memberikan rasa nyaman bagi seluruh masyarakat sosial maupun lingkungan.

Sebagai bagian dari pembentukan citra positif dan strategi dalam menghadapi krisis yang sedang dihadapi dan kemungkinan terjadinya krisis di masa mendatang. Sesuai dengan misi Indocement yaitu berkecimpung dalam bisnis penyediaan semen dan bahan bangunan berkualitas dengan harga kompetitif dan tetap memperhatikan pembangunan berkelanjutan.

Isu pencemaran lingkungan yang diangkat adalah: (a) memunculkan polusi, (b) kebisingan dan kerusakan fungsi lingkungan akan berdampak pada menyusutnya debit air dan kekeringan, (c) perusakan fungsi hutan yang selama ini mampu untuk menampung air hujan sehingga mengurangi besaran air dan derasnya banjir, berpotensi banjir bandang, (d) penurunan tingkat produksi tanaman pangan, (e) debu dari hasil pembakaran batu bara menutup 
stomata daun sehingga menurunkan tingkat produktivitas tanaman (Walhi, 2014).

Hal ini telah mencemarkan nama baik perusahaan dan hilangnya kepercayaan masyarakat yang berhubungan dengan kegiatan operasionalnya. Berdasarkan pemaparan di atas, peneliti ingin mengetahui "Program corporate social responsibility PT Indocement Tunggal Prakarsa Tbk. dalam Program "Pendampingan Kelompok Batik Tulis Pewarna Alam" di Masyarakat Kecamatan Ciwaringin Cirebon".

Penelitian ini menggunakan pendekatan kuantitatif eksplanatif. Populasi dari penelitian ini adalah seluruh penerima program Pendampingan Kelompok Batik Tulis Pewarna Alam di Kecamatan Ciwaringin dengan jumlah anggota sebanyak 77 orang, keseluruhan populasi merangkap sebagai sampel penelitian.

Penyebaran instrumen penelitian menggunakan sampel jenuh/sensus (total sampling). Teknik pengumpulan data yang digunakan dalam penelitian ini, yaitu: angket, observasi, wawancara, dan studi kepustakaan. Kemudian skala penilaian jawaban angket yang digunakan adalah skala interval dengan kategori model Likert.

\section{METODE PENELITIAN}

Penelitian ini mengunakan pendekatan kuantitatif eksplanatif. Menurut Kriyantono penelitian kuantitatif bersifat objektif dan tidak mengikutsertakan analisis dan interpretasi subjektif peneliti. Selain itu, pendekatan kuantitatif juga menggunakan uji statistik untuk menganalisa data dan hasilnya dapat digeneralisasikan dari sampel yang representatif (Kriyantono, 2010: 56). Penelitian eksplanatif memiliki dua sifat yaitu komparatif dan asosiatif. Penelitian asosiatif bertujuan untuk mengetahui ada tidaknya hubungan antar dua variabel atau lebih. Dimana hubungan tersebut dapat bersifat positif atau negatif (Kriyantono, 2010: 56). Metode ini dipilih karena sesuai dengan tujuan penelitian, yaitu untuk mendeskripsikan Program corporate social responsibility (CSR) yang dilaksanakan oleh PT Incocement Tunggal Perkasa.

Dalam penelitian ini, peneliti telah menentukan partisipan yang jelas agar penelitian lebih terfokus. Partisipan yang terlibat dalam penelitian adalah penerima program Pendampingan Kelompok Batik Tulis Pewarna Alam di Kecamatan Ciwaringin.

Alasan pemilihan penerima program Pendampingan Kelompok Batik Tulis Pewarna Alam di Kecamatan Ciwaringin karena program ini merupakan salah satu program SDP PT Indocement plant Cirebon jadi dampaknya akan dirasakan oleh penerima program secara berkelanjutan, bukan hanya saat pelaksanaan program. Selain itu program tersebut juga menerapkan sistem produksi bersih dan ramah 
lingkungan, dengan memperhatikan kesehatan dan keselamatan pengrajin dan pengelolaan limbahnya. Kemudian daftar penerima program tersebut sangat jelas sehingga memudahkan peneliti dalam penelitian ini.

Populasi adalah wilayah generalisasi yang terdiri atas: objek/subjek yang mempunyai kualitas dan karakteristik tertentu yang ditetapkan oleh peneliti untuk dipelajari dan kemudian ditarik kesimpulannya. (Sugiyono, 2007: 61). Populasi dari penelitian ini adalah seluruh penerima program Pendampingan Kelompok Batik Tulis Pewarna Alam di Kecamatan Ciwaringin dengan jumlah anggota sebanyak 77 orang, keseluruhan populasi dijadikan sebagai sampel penelitian dengan menjadikan seluruh populasi merupakan sampel jenuh.

Penyebaran instrumen penelitian menggunakan sampel jenuh/sensus (total sampling). Menurut Surakhmad dalam Bungin (2005: 111). Tidak semua penelitian menggunakan sampel sebagai sasaran penelitian pada penelitan tertentu dengan skala kecil, yang hanya memerlukan beberapa orang sebagai objek penelitian ataupun beberapa penelitian kuantitatif yang dilakukan terhadap objek atau populasi kecil, biasanya penggunaan sampel penelitian tidak diperlukan. Hal tersebut karena keseluruhan objek penelitian dapat dijangkau oleh peneliti.
Dalam istilah penelitian kuantitatif, objek penelitian yang kecil ini disebut sampel total, yaitu keseluruhan populasi merangkap sebagai sampel penelitian. Hikmat (2011: 65) mengungkapkan bahwa semakin besar jumlah sampel mendekati jumlah populasi, maka peluang kesalahan generalisasi semakin kecil. Adapun teknik pengumpulan data menggunakan angket, observasi, wawancara dan studi dokumentasi.

Metode analisis data dengan cara menyusun data, mengelompokkannya, selanjutnya menginterpretasikannya, sehingga diperoleh gambaran yang sebenarnya mengenai corporate social responsibility, yang berpengaruh terhadap citra perusahaan. Analisis data ini dilakukan untuk menjawab pertanyaan-pertanyaan yang telah dirumuskan dalam rumusan masalah. Untuk menjawab rumusan masalah no. 1 dan rumusan masalah no. 2 maka teknik analisis data yang digunakan adalah analisis deskriptif, yakni untuk mengetahui gambaran tingkat corporate social responsibility PT Indocement Tunggal Prakarsa Tbk di Masyarakat Kecamatan Ciwaringin Cirebon.

Sesuai dengan tujuan penelitian ini, yakni untuk mendeskripsikan program corporate social responsibility PT Indocement Tunggal Prakarsa Tbk di Masyarakat Kecamatan Ciwaringin Cirebon. Berdasarkan pemaparan tersebut, analisis data dalam penelitian ini 
akan diarahkan untuk menjawab permasalahan sebagaimana diungkapkan pada rumusan masalah.

Mengingat skala pengukuran dalam menjaring data penelitian ini seluruhnya diukur dalam skala ordinal, yaitu skala yang berjenjang yang diperoleh dari pengukuran skala ini disebut data yang berjenjang yang jarak antara satu data dengan data yang lain tidak sama (Sugiyono, 2007: 70). Tetapi di lain pihak pengolahan data dengan penerapan statistik parametrik mensyaratkan data sekurangkurangnya harus diukur dalam skala interval maka terlebih dahulu data skala ordinal tersebut ditransformasikan menjadi data interval dengan menggunakan metode succesive interval.

Menurut Ardianto (2011: 188), validitas menunjukkan sejauh mana alat ukur yang digunakan mengukur sesuatu. Uji validitas ini dilakukan untuk mengetahui tingkat kevalidan dari suatu instrumen, artinya bahwa instrumen yang dipakai benar-benar mengukur apa yang seharusnya diukur.

Secara teknis pengujian instrument dengan rumus-rumus di atas menggunakan bantuan software SPSS (Statistical Package for the Social Sciences) versi 16.0. Adapun langkahlangkah untuk uji validitas menggunakan SPSS versi 16.0, adalah sebagai berikut: (1) Mengkoding data mentah yang didapatkan dari kuesioner yang sudah diisi oleh responden; (2)
Menjumlahkan nilai (skor) yang diperoleh dari masing-masing responden; (3) Masukkan data tersebut ke SPSS; (4) Klik analyze correlate bivariate; (5) Memasukkan seluruh item pernyataan ke kolom sebelah kanan, hal ini berfungsi untuk menganalisis seluruh validitas pada setiap item; (6) Memberi tanda checklist pada option Pearson dan Two-tail, lalu klik OK; dan (7) Untuk melihat hasil validitas setiap item pernyataan, dapat dilihat pada kolom paling akhir (kolom jumlah score).

Pengujian validitas yaitu corporate social responsibility dalam penelitian ini dilakukan terhadap 30 responden dengan tingkat signifikasi 5\% dan derajat kebebasan (df) n-2 yaitu $30-2=28$, sehingga diperoleh nilai rtabel sebesar 0,374. Satu pernyataan dalam kuesioner dikatakan tidak valid, selebihnya pernyataan dalam kuisioner dikatakan valid karena setiap item pernyataan memiliki ri(x-i) lebih besar daripada rtabel (ri(x-i) >rtabel), artinya pernyataan-pernyataan dalam kuesioner dapat dijadikan alat ukur apa yang hendak diukur. Hasil dari uji validitas ini adalah 19 item pertanyaan dinyatakan valid.

Formula yang dipergunakan untuk menguji reliabilitas instrumen dalam penelitian ini adalah Koefisien Alfa dari Cronbach, sebagai berikut:

$$
r_{\mathrm{II}}=\left[\frac{k}{k-1}\right]\left[1-\frac{\sum \sigma_{i}^{2}}{\sigma_{t}^{2}}\right]
$$


Dimana: Rumus varians sebagai berikut:

$$
\sigma^{2}=\frac{\sum X^{2}-\frac{\left(\sum X\right)^{2}}{N}}{N}
$$

Keterangan:

$=$ Reliabilitas instrumen/koefisien alfa

= Banyaknya bulir soal

$=$ Jumlah varians bulir

$=$ Varians total

$=$ Jumlah skor

$=$ Jumlah responden

(Arikunto, 2006: 184)

Suatu variabel dikatakan reliable, jika hasil $\alpha=>0,60=$ reliable dan hasil $\alpha<0,60=$ tidak reliable". Untuk mengetahui hasil uji reliabilitas dengan menggunakan SPSS versi 16.0 yaitu sebagai berikut: (1) Mengkoding data mentah yang didapatkan dari kuesioner yang sudah diisi oleh responden; (2) Menjumlah nilai responden yang diperoleh dari masing-masing responden; (3) Masukkan data tersebut ke SPSS; (4) Lalu klik Analyze Scale Reliability Analysis; (5) Memasukkan seluruh item pernyataan ke kolom sebelah kanan, hal ini berfungsi untuk menganalisis reliabilitas seluruh data; (6) Pilih Alpha untuk option model peneliti gunakan, lalu klik OK; dan (7) Hasil reliabilitas dapat dilihat di tabel 'Reliability Statistic'. Berdasarkan hasil perhitungan uji reliabilitas, pada corporate social responsibility memiliki nilai 0,957 yang memiliki koefisien korelasi lebih besar dari kriteria uji yaitu sebesar 0,60 yang berarti instrument penelitian adalah reliabel (teruji keandalannya).

Penggunaan analisis parametris seperti analisis perbandingan dua rata-rata, analisis variansi satu arah, korelasi, regresi dan sebagainya, maka perlu dilakukan uji normalitas data terlebih dahulu. Hal ini bertujuan untuk mengetahui apakah data tersebut berdistribusi normal atau tidak. Normalitas suatu data penting karena dengan data yang berdistribusi normal atau mendekati normal, maka data tersebut terdistribusi normal dan data dianggap dapat mewakili suatu populasi.

Maka dari itu pengolahan data normalitas tersebut dapat dilakukan dengan bantuan program SPSS versi 16.0. Adapun langkahlangkah yang dapat dilakukan sebagai berikut: (1) Masukkan data yang akan diuji normalitasnya di data view, sedangkan di variabel view beri nama data tersebut. Kemudian klik analyze atau regression, kemudian klik linier. Masukkan variabel Y pada kotak dependent dan variabel X pada kotak independent dan (2) Klik plots, lalu pada Y pilih dependent sedangkan X diisi zresid. Pada standardized residual plots klik histogram dan normal probability plots, lalu klik continue. 
HASIL DAN PEMBAHASAN

Kotler dan Lee mengungkapkan corporate social responsibility adalah komitmen untuk meningkatkan kesejahteraan masyarakat melalui praktik-praktik bisnis "sukarela" dan kontribusi dari sumber daya perusahaan (2005: 3). Sejalan dengan definisi sebelumnya yang diungkapkan oleh Elkington (1998) CSR adalah operasi bisnis yang berkomitmen tidak hanya untuk meningkatkan keuntungan perusahaan secara finansial, melainkan pula untuk pembangunan sosial-ekonomi kawasan secara holistik, melembaga, dan berkelanjutan. Di sisi lain, menurut Fuad (2017) CSR merupakan suatu bentuk tindakan nyata perusahaan atau kepekaan dan kepedulian untuk berkontribusi terhadap lingkungan sosial dalam memberikan manfaat, menyelesaikan masalah, serta meningkatkan kualitas hidup masyarakat.

Menurut Kurtz dan Boone dalam Jurnal Corporate social responsibility: a study of Kazakhstan corporate sector yang ditulis oleh Rajasekhara (2010: 36) salah satu hal yang menyebabkan bahwa CSR diperlukan adalah untuk meningkatkan citra perusahaan. Hal ini senada dengan pernyataan Nugraha (2015) yang menyatakan bahwa keberhasilan program CSR tidak diperoleh hanya dalam waktu singkat, tetapi butuh waktu dan proses yang lebih lama yang dilakukan secara terusmenerus, terencana, dan terukur. Data hasil penelitian yang telah dilakukan peneliti mengenai corporate social responsibility dapat memberikan gambaran tentang economic, legal, ethical, dan directionary.

Tabel 1 Rekapitulasi Jumlah Skor Jawaban Responden Mengenai Variabel Corporate Social Responsibility(CSR)

\begin{tabular}{cccccc}
\hline No & Dimensi & Total Skor & Total Pernyataan & Rata-Rata Skor & \% Skor \\
\hline 1 & Ethical & 1230 & 4 & 307,5 & 25,6 \\
2 & Legal & 580 & 2 & 290 & 24,2 \\
3 & Economic & 589 & 2 & 294,5 & 24,4 \\
4 & Directionary & 3415 & 11 & 310,4 & 25,8 \\
\hline & Total & 5814 & 19 & 1202,4 & 100 \\
\hline
\end{tabular}

Sumber: Hasil Olahan Data Peneliti (2016) 


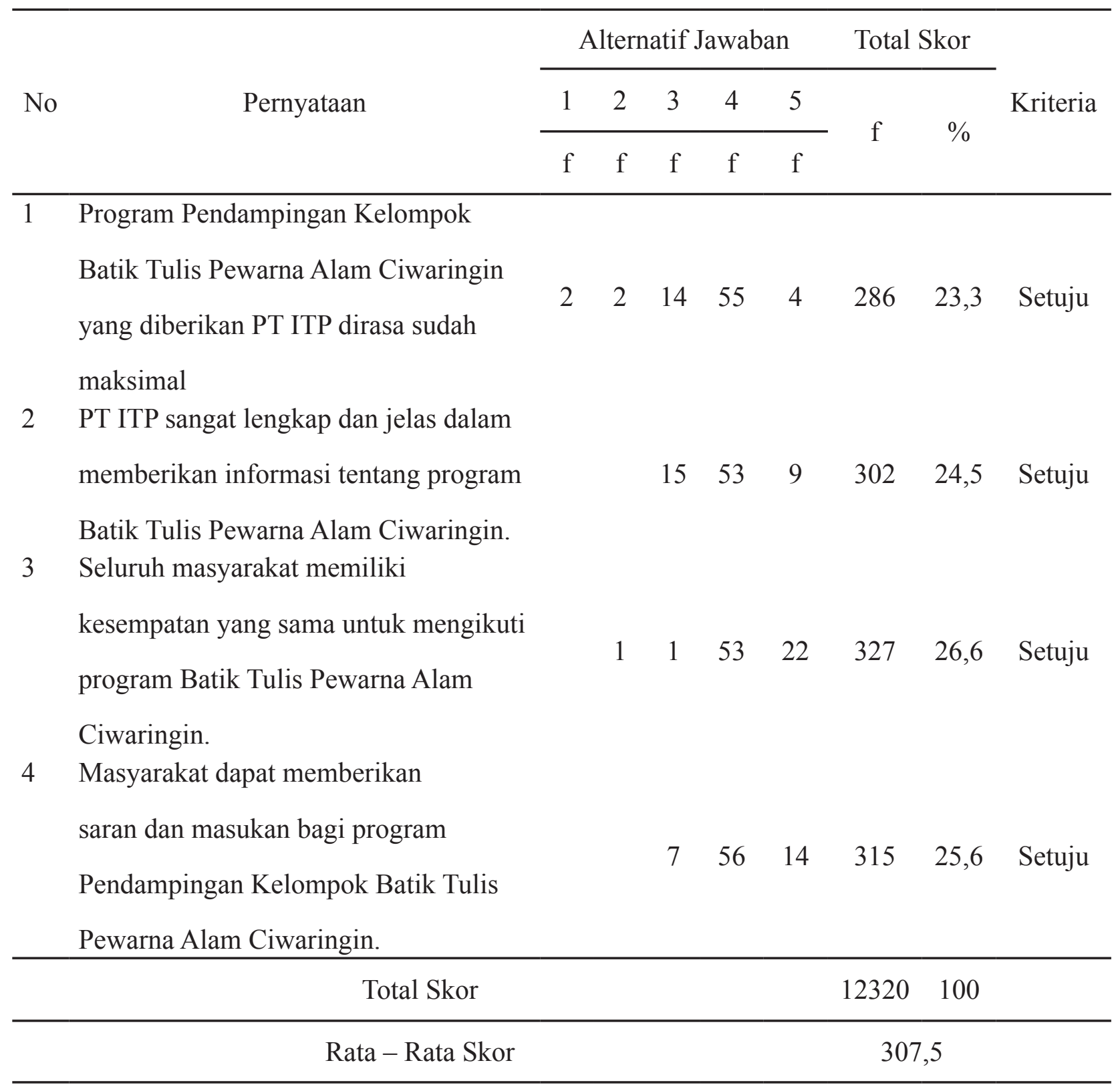

Sumber: Hasil Olahan Data Peneliti (2016)

Berdasarkan Tabel 2 mengenai tanggapan responden terhadap dimensi ethical, yang paling tinggi yaitu pada item pernyataan tentang seluruh masyarakat memiliki kesempatan yang sama untuk mengikuti program Batik Tulis Pewarna Alam Ciwaringin yaitu sebesar 327 atau $26,6 \%$ dari sampel menyatakan setuju. Sedangkan tanggapan responden yang paling rendah pada item pernyataan Program Pendampingan Kelompok Batik Tulis Pewarna Alam Ciwaringin yang diberikan PT ITP dirasa sudah maksimal dengan perolehan skor yaitu 286 atau $23,3 \%$.

Berdasarkan hasil penelitian data tersebut 
maka didapatkan hasilnya bahwa dimensi ethical setuju bahwa perusahaan sudah bertindak secara etis. Hal tersebut dibuktikan dengan hasil Tabel 2 dengan jumlah skor dari empat butir pertanyaan yang digunakan sebesar 1230, sehingga jika dirata-ratakan akan mendapatkan skor sebesar 307,5 ini termasuk ke dalam kategori baik.

Menurut Carrol (1999: 279) bahwa "perusahaan harus melakukan apa yang benar, adil, dan wajar bahkan ketika mereka tidak diharuskan melakukannya oleh kerangka hukum". Sejalan dengan kutipan di atas, di dalam penelitian ini didapatkan bahwa responden menyatakan bahwa program CSR sudah berjalan maksimal dan jelas dalam pemberian informasi mengenai program, maka dari itu dapat dikatakan bahwa jumlah bantuan yang diterima masyarakat sudah didukung oleh tindakan yang perusahaan lakukan.

Berdasarkan hasil pengumpulan data dari 77 responden mengenai dimensi legal dapat dilihat pada tabel 3. Berdasarkan Tabel 3 mengenai tanggapan responden terhadap indikator aturanaturan dalam program dapat diandalkan yang paling tinggi yaitu pada item pernyataan tentang proses pelaksanaan program dilakukan secara konsisten dan terkonsep dengan baik yaitu sebesar 305 atau 52,5\%.

Tanggapan responden yang paling rendah yaitu pada item pertanyaan mengenai PT Indocement memberikan kesempatan kerja

\section{Tabel 3 Dimensi Legal}

\begin{tabular}{llllllllll}
\hline & & \multicolumn{7}{c}{ Alternatif Jawaban } & \multicolumn{1}{c}{ Total Skor } \\
\cline { 2 - 7 } No & Pernyataan & 1 & 2 & 3 & 4 & 5 & & \\
\cline { 2 - 7 } & & $\mathrm{f}$ & $\mathrm{f}$ & $\mathrm{f}$ & $\mathrm{f}$ & $\mathrm{f}$ & $\mathrm{f}$ & $\%$ \\
\hline
\end{tabular}

Proses pelaksanaan program

Pendampingan Kelompok Batik Tulis

1 Pewarna Alam Ciwaringin dilakukan $\begin{array}{llllllll}- & 1 & 8 & 61 & 7 & 305 & 52,5 & \text { Setuju }\end{array}$ secara konsisten dan terkonsep dengan baik.

PT Indocement memberikan kesempatan $\begin{array}{llllllllll}2 & \text { kerja terhadap tenaga kerja asing dan } & 1 & 9 & 17 & 45 & 5 & 275 & 47,5 & \text { Setuju }\end{array}$ berkebutuhan khusus.

\begin{tabular}{ccc}
\hline Total Skor & 580 & 100 \\
\hline Rata - Rata Skor & 290 \\
\hline
\end{tabular}


terhadap tenaga kerja asing dan berkebutuhan khusus dengan perolehan skor yaitu 275 atau 47,5\%. Berdasarkan hasil penelitian data tersebut maka didapatkan hasilnya bahwa aturan-aturan dalam program dapat di andalkan dinyatakan oleh mereka dengan setuju. Hal tersebut dibuktikan dengan hasil tabel 3 dengan jumlah skor dari dua butir pernyataan yang digunakan sebesar 580, sehingga jika dirataratakan akan mendapatkan skor sebesar 290 ini termasuk ke dalam kategori baik.

Menurut Carrol (1999: 280) bahwa, "Perusahaan harus mematuhi standar-standar yang merupakan prasyarat yang diperlukan untuk alasan lebih lanjut mengenai tanggung jawab sosial". Sehingga dalam penelitian responden menyatakan setuju dengan indikator aturan-aturan dalam program dapat diandalkan karena sesuai dengan yang dirasakan dalam pelaksanaan program. Hal ini sejalan dengan yang dikemukakan oleh Carrol di atas. Dengan demikian, senada dengan yang disampaikan oleh Nurjanah (2013) bahwa CSR suatu perusahaan merupakan suatu kegiatan di atas kewajiban sebagai perusahaan yang bergerak di bidang bisnis dengan tujuan untuk meningkatkan kesejahteraan komunitas dan memelihara lingkungan hidup.

Berdasarkan Tabel 4 mengenai tanggapan responden terhadap dimensi economic yang paling tinggi yaitu pada item pernyataan tentang program Pendampingan Kelompok Batik Tulis Pewarna Alam Ciwaringin telah diterima oleh orang-orang yang tepat sasaran yaitu sebesar 302 atau 51,3\%. Tanggapan responden yang paling rendah yaitu pada item pertanyaan

\section{Tabel 4 Dimensi Economic}

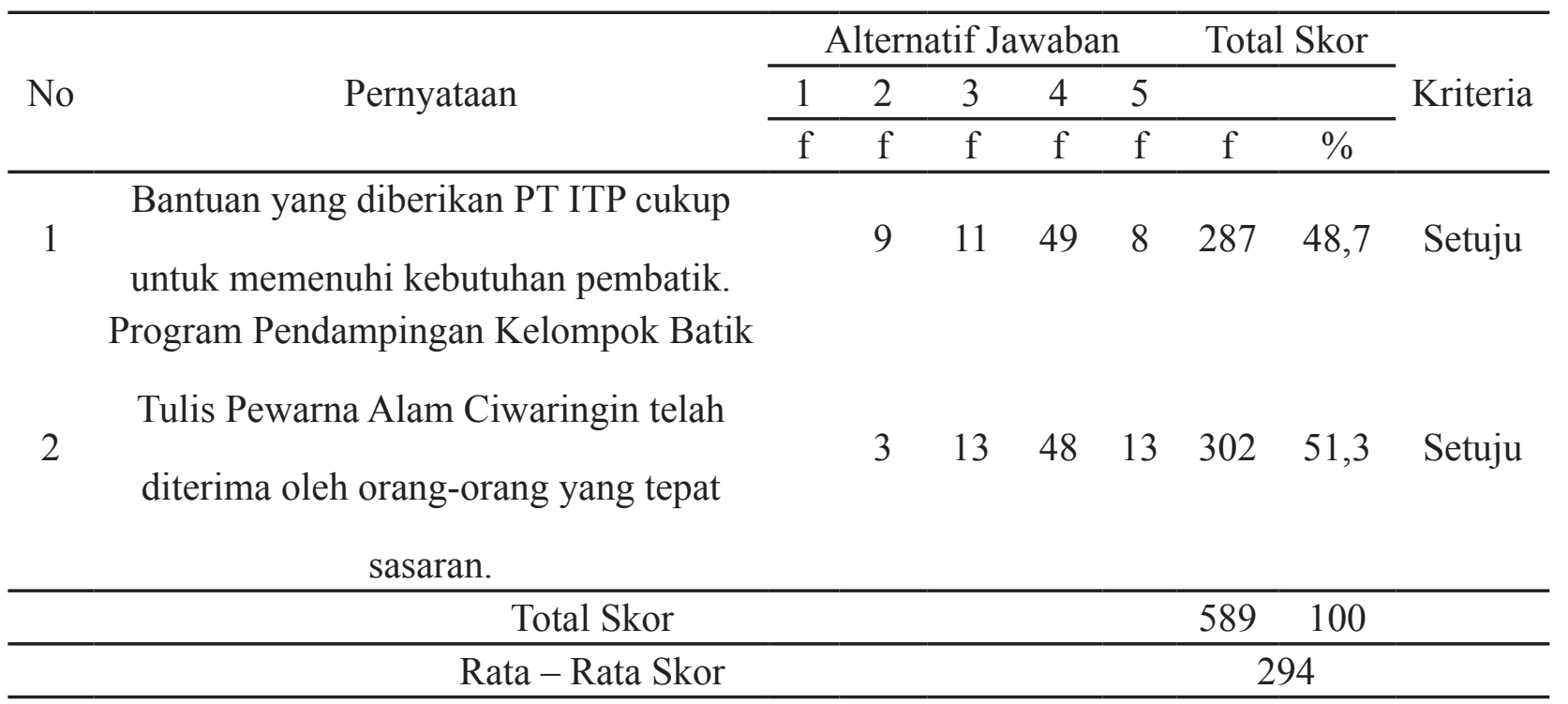




\begin{tabular}{|c|c|c|c|c|c|c|c|c|}
\hline \multirow{3}{*}{ No } & \multirow{3}{*}{ Pernyataan } & \multicolumn{4}{|c|}{ Alternatif Jawaban } & \multicolumn{2}{|c|}{ Total } & \multirow{3}{*}{ Kriteria } \\
\hline & & 12 & 3 & 4 & 5 & & & \\
\hline & & $\mathrm{f}$ & $\mathrm{f}$ & $\mathrm{f}$ & $\mathrm{f}$ & $\mathrm{f}$ & $\%$ & \\
\hline 1 & $\begin{array}{l}\text { Pelatihan soft skill yang diberikan mampu } \\
\text { membentuk karakter pengrajin batik unggul. }\end{array}$ & 1 & 10 & 54 & 12 & 308 & 9.1 & Setuju \\
\hline 2 & $\begin{array}{l}\text { PT ITP terkenal baik dalam pemberian } \\
\text { pelatihan soft skill-nya. }\end{array}$ & 4 & 5 & 59 & 9 & 304 & 8,9 & Setuju \\
\hline 3 & $\begin{array}{l}\text { Berkat program Pendampingan Kelompok } \\
\text { Batik Tulis Pewarna Alam Ciwaringin taraf } \\
\text { ekonomi masyarakat meningkat. }\end{array}$ & 2 & 17 & 51 & 7 & 294 & 8,6 & Setuju \\
\hline 4 & $\begin{array}{l}\text { PT ITP terpercaya dalam memberikan pelatihan } \\
\text { program Batik Tulis Pewarna Alam Ciwaringin. }\end{array}$ & - & 8 & 61 & 8 & 308 & 9,0 & Setuju \\
\hline 5 & $\begin{array}{l}\text { Perusahaan ikut serta dalam penyediaan } \\
\text { fasilitas membatik bagi Kelompok Batik Tulis }\end{array}$ & 3 & 7 & 58 & 9 & 304 & 8,9 & Setuju \\
\hline & Pewarna Alam Ciwaringin. & & & & & & & \\
\hline 6 & $\begin{array}{l}\text { PT ITP mengadakan program Pendampingan } \\
\text { Kelompok Batik Tulis Pewarna Alam }\end{array}$ & 3 & 11 & 41 & 22 & 313 & 9,1 & Setuju \\
\hline & $\begin{array}{l}\text { Ciwaringin sebagai wujud konsistensi dalam } \\
\text { membantu ekonomi masyarakat Indonesia. }\end{array}$ & & & & & & & \\
\hline 7 & $\begin{array}{l}\text { PT ITP mengadakan program Pendampingan } \\
\text { Kelompok Batik Tulis Pewarna Alam }\end{array}$ & - & 10 & 49 & 18 & 316 & 9,2 & Setuju \\
\hline & $\begin{array}{l}\text { Ciwaringin sebagai wujud komitmen dalam } \\
\text { membantu ekonomi masyarakat Indonesia. }\end{array}$ & & & & & & & \\
\hline 8 & $\begin{array}{l}\text { PT ITP berkontribusi dalam meningkatkan taraf } \\
\text { ekonomi masyarakat. }\end{array}$ & 2 & 9 & 49 & 17 & 312 & 9,1 & Setuju \\
\hline 9 & Karena adanya programPendampingan & 3 & 8 & 45 & 21 & 315 & 9,2 & Setuju \\
\hline & $\begin{array}{l}\text { Kelompok Batik Tulis Pewarna Alam } \\
\text { Ciwaringin semakin banyak masyarakat yang } \\
\text { memperoleh keahlian membatik. }\end{array}$ & & & & & & & \\
\hline 10 & $\begin{array}{l}\text { Program Pendampingan Kelompok Batik } \\
\text { Tulis Pewarna Alam Ciwaringin memotivasi }\end{array}$ & 2 & 6 & 47 & 22 & 320 & 9,3 & Setuju \\
\hline
\end{tabular}



11 Pendampingan Kelompok Batik Tulis Pewarna
2646
$23 \quad 321 \quad 9,4 \quad$ Setuju
Alam Ciwaringin memberikan motivasi bagi
masyarakat yang tidak mampu untuk menaikan
taraf ekonomi keluarga.

\begin{tabular}{ccc}
\hline Total Skor & 589 & 100 \\
\hline Rata - Rata Skor & 294 \\
\hline
\end{tabular}

Sumber: Hasil Olahan Data Peneliti (2016)

mengenai bantuan yang diberikan PT ITP cukup untuk memenuhi kebutuhan pembatik dengan perolehan skor yaitu 287 atau $48,7 \%$.

Berdasarkan hasil penelitian data tersebut maka didapatkan hasilnya bahwa dimensi economic dinyatakan oleh mereka dengan setuju. Hal tersebut dibuktikan dengan hasil Tabel 4 dengan jumlah skor dari dua butir pernyataan yang digunakan sebesar 589, sehingga jika dirata-ratakan akan mendapatkan skor sebesar 294 ini termasuk ke dalam kategori baik.

Menurut Carrol (1999: 280) bahwa, "Tanggung jawab pertama perusahaan adalah menjadi unit ekonomi yang berfungsi dan untuk bertahan dalam usahanya". Sehingga dalam penelitian ini responden menyatakan setuju dengan dua butir pernyataan diatas bantuan yang diberikan PT ITP cukup untuk memenuhi kebutuhan pembatik. Hal ini sejalan dengan yang diungkapkan oleh Carrol di atas.

Berdasarkan hasil pengumpulan data dari 77 responden mengenai dimensi directionary dapat dilihat pada tabel 5. filosofi "the love of the fellow human" dan
Berdasarkan Tabel 5 mengenai tanggapan responden terhadap dimensi directionary yang paling tinggi yaitu pada item pernyataan tentang pendampingan Kelompok Batik Tulis Pewarna Alam Ciwaringin memberikan motivasi bagi masyarakat yang tidak mampu untuk menaikan taraf ekonomi keluarga yaitu sebesar 321 atau $9,4 \%$.

Berdasarkan hasil penelitian data tersebut maka didapatkan hasilnya bahwa dimensi directionary dinyatakan oleh mereka dengan setuju. Hal tersebut dibuktikan dengan hasil Tabel 5 dengan jumlah skor dari 11 butir pernyataan yang digunakan sebesar 3415, sehingga jika dirata-ratakan akan mendapatkan skor sebesar 310,4 ini termasuk ke dalam kategori baik.

Sehingga disimpulkan responden menyatakan setuju bahwa perusahaan dapat memberikan manfaat bagi mereka melalui program tersebut. Hal ini sejalan dengan yang dikemukakan oleh Carrol (1999: 281) bahwa tanggung jawab filantropis didasarkan pada 
Tabel 6 Pedoman Kriteria dan Kategorisasi Variabel Corporate Social Responsibility

\begin{tabular}{ccc}
\hline Rentang Nilai & Kriteria (Tidak setuju - Setuju) & Kategori Penafsiran Variabel X \\
\hline $1463-2633$ & 1 (Sangat Tidak Setuju) & Sangat Tidak Baik \\
$2634-3804$ & 2 (Tidak Setuju) & Tidak Baik \\
$3805-4975$ & 3 (Tidak Pasti/Netral) & Cukup Baik \\
$4976-6146$ & 4 (Setuju) & Baik \\
$6147-7317$ & 5 (Sangat Setuju) & Sangat Baik \\
\hline
\end{tabular}

Sumber: Hasil Olahan Data Peneliti (2016)

dengan didasarkan pada ide bahwa dalam konteks bisnis, menuntut perusahaaan untuk mengadakan kebijaksanaan sebagai usaha meningkatkan kualitas hidup karyawan, masyarakat setempat dan akhirnya masyarakat secara luas.

Hasil gambaran secara menyeluruh mengenai variabel CSR, dilakukan kategorisasi terhadap jumlah skor tanggapan responden atas ke-19 butir pernyataan. peneliti melakukan kategorisasi berdasarkan skor tertinggi dan terendah. Untuk menghitung skor tertinggi dan terendah dapat menggunakan cara sebagai berikut: (1) Mencari nilai indeks maksimum $($ tertinggi $)=$ skor tertinggi $\mathrm{x}$ jumlah pernyataan x jumlah responden $(5 \times 19$ x $77=7315)$; (2) Mencari nilai indeks minimum (terendah) = skor terendah $\mathrm{x}$ jumlah pernyataan $\mathrm{x}$ jumlah responden ( 1 x 19 x $77=1463)$; dan (3) Jarak interval $=($ skor tertinggi - skor terendah $)$ : jumlah kelas interval $(7315-1463): 5=1170,4$ $=1170$.
Skor tertinggi yang mungkin diperoleh adalah 7315 dan skor terendah yang mungkin diperoleh adalah 1463. Jika dibagi ke dalam 5 kategori, panjang kelas interval untuk setiap kategori adalah 1170. Jadi nilai interval untuk setiap kategori dapat disusun dalam tabel 6 .

Berdasarkan Gambar 1 dapat disimpulkan bahwa corporate social responsibility memberikan hasil yang termasuk dalam kategori penafsiran baik. Hal ini dapat dilihat dari total jumlah skor sebesar 5814 berada pada interval 4976 - 6146 yang termasuk dalam kategori baik.

Lako mengungkapkan dari perspektif teori sistem bahwa kesuksesan dan hidup matinya suatu perusahaan akan tergantung pada kemampuannya menyeimbangkan beragam kepentingan dari para stakeholder atau pemangku kepentingan. Jika mampu, maka perusahaan akan meraih dukungan yang berkelanjutan dan menikmati pertumbuhan pangsa pasar (Lako, 2011: 5). 
Sejalan dengan yang diungkapkan Lako, dasar pemikiran lainnya mengenai teori pemangku kepentingan yaitu percaya bahwa hubungan perusahaan-pemangku kepentingan merupakan aset berharga dan mendasar yang harus dikelola oleh top manajer suatu perusahaan (Post dalam Jamali, 2008: 16). Teori tersebut menjelaskan variabel corporate social responsibility tercipta oleh pengelolaan publik perusahaan, sehingga akan terlihat apakah program baik atau tidak.
Berdasarkan Gambar 1, setelah tanggapan responden diakumulasi maka dihasilkan pernyataan setuju atau dengan kata lain responden setuju bahwa corporate social responsibility di perusahaan baik. Berdasarkan hasil akumulasi data secara keseluruhan mengenai tanggapan responden terhadap corporate social responsibility memberikan hasil yang termasuk dalam kategori penafsiran baik. Hal ini dapat dilihat dari total jumlah skor sebesar 5814 berada pada interval

Tabel 7 Rekapitulasi Jumlah Skor Jawaban Responden Mengenai Variabel Corporate Social Responsibility (CSR)

\begin{tabular}{cccccc}
\hline No & Dimensi & Total Skor & Total Pernyataan & Rata-Rata Skor & \% Skor \\
\hline 1 & Ethical & 1230 & 4 & 307,5 & 25,6 \\
2 & Legal & 580 & 2 & 290 & 24,2 \\
3 & Economic & 589 & 2 & 294,5 & 24,4 \\
4 & Directionary & 3415 & 11 & 310,4 & 25,8 \\
\hline \multirow{2}{*}{ Total } & 5814 & 19 & 1202,4 & 100 & \\
\hline
\end{tabular}

Sumber: Hasil Olahan Data Peneliti (2016)

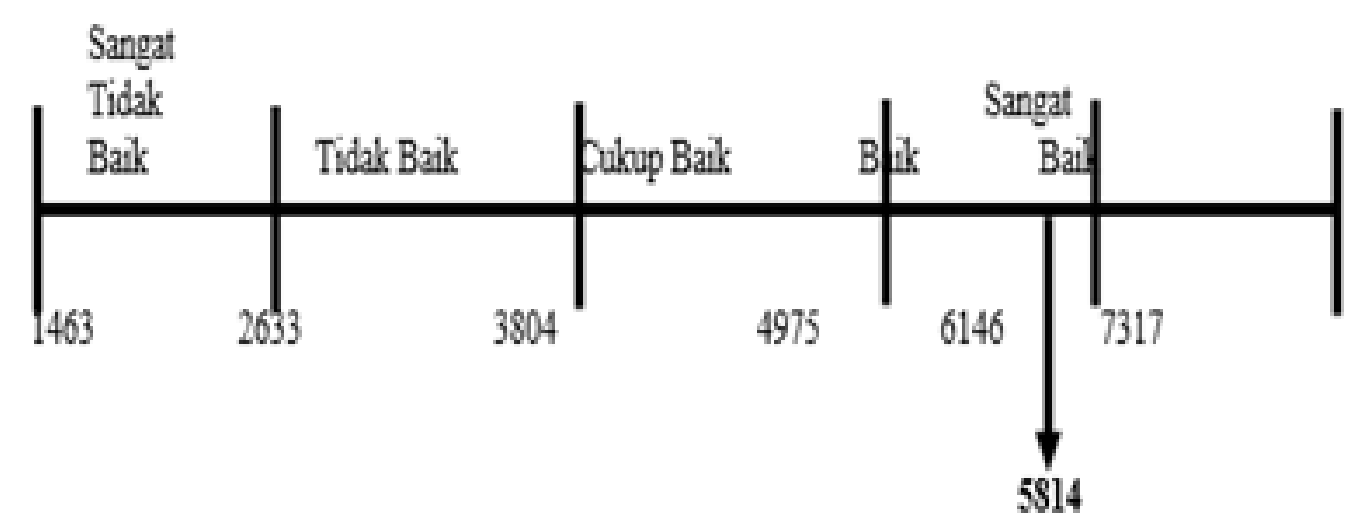

Sumber: Hasil Olahan data Peneliti (2016)

Gambar 1 Rekapitulasi Jumlah Skor Jawaban Responden Mengenai Corporate Social Responsibility (CSR) 
4976 - 6146 yang termasuk dalam kategori

baik. Lako mengungkapkan dari perspektif teori sistem bahwa kesuksesan dan hidup matinya suatu perusahaan akan tergantung pada kemampuannya menyeimbangkan beragam kepentingan dari para stakeholder atau pemangku kepentingan. Jika mampu, maka perusahaan akan meraih dukungan yang berkelanjutan dan menikmati pertumbuhan pangsa pasar (Lako, 2011: 5).

Sejalan dengan yang diungkapkan Lako, dasar pemikiran lainnya mengenai teori pemangku kepentingan yaitu percaya bahwa hubungan perusahaan-pemangku kepentingan merupakan aset berharga dan mendasar yang harus dikelola oleh top manajer suatu perusahaan (Post dalam Jamali, 2008: 16). Teori di atas menjelaskan variabel corporate social responsibility tercipta oleh pengelolaan publik perusahaan, sehingga akan terlihat apakah program baik atau tidak. Setelah diakumulasi maka dihasilkan pernyataan setuju atau dengan kata lain responden setuju bahwa corporate social responsibility di perusahaan baik.

\section{SIMPULAN}

Hasil penelitian ini dapat disimpulkan bahwa masih terdapatnya berbagai faktor yang menentukan tingkat citra perusahaan. Meskipun hasil penelitian sudah menjawab bahwa citra perusahaan dalam tingkat baik dengan menyatakan setuju, tetapi aspek lainnya masih ada responden yang menyatakan tidak setuju. Citra perusahaan inilah yang menjadi ukuran sampai mana gambaran citra PT Indocement Tunggal Prakarsa Tbk. di masyarakat Kecamatan Ciwaringin.

CSR selain mampu meningkatkan kualitas kehidupan sosial juga mampu meningkatkan daya saing perusahan karena berhubungan dengan lingkungan, sosial dan tentunya mendapat dukungan dari masyarakat. Jika kita memperhatikan dukungan dari masyarakat ini khususnya masyarakat yang berada di sekitar perusahaan sangat penting untuk meningkatkan citra perusahaan-perusahaan di Indonesia khususnya citra perusahaan PT Indocement. Sebuah perusahaan tidak dapat dipungkiri membutuhkan kegiatan CSR untuk meminimalisir risiko atau citra negatif. Namun, pada prakteknya banyak perusahaan yang hanya melaksanakan CSR sebagai "topeng” dan tidak memperhatikan aspek keberlanjutan.

Program corporate social responsibility di PT Indocement Tunggal Prakarsa Tbk. berada pada kategori baik atau responden menyatakan dalam kriteria setuju. Dimensi yang memperoleh skor rata-rata tertinggi yaitu directionary, hal tersebut menunjukan bahwa masyarakat mengganggap bahwa keberadaan perusahaan memberikan manfaat bagi mereka. Sedangkan dimensi yang memperoleh skor rata- 
rata terendah adalah personality yang berarti masyarakat belum memahami perusahaan seperti perusahaan dapat dipercaya.

\section{DAFTAR PUSTAKA}

Ardianto, E. \& Soemirat, S. (2010). Dasardasar public relations. Bandung: Remaja Rosda Karya.

Arikunto. S. (2006). Prosedur penelitian suatu pendekatan praktik. Jakarta: Rineka Cipta.

Bungin, B. (2005). Metodologi penelitian kuantitatif. Jakarta: Kencana.

Carroll, S. J. \& H. I. Tosi. (1970). Goal characteristics and personality factors in a management by objectives program. Administrative Science Quarterly, 15 (1970), pp. 295-305.

Fuad, A. V. (2017). Health agent award sebagai corporate social responsibility pt. nutrifood indonesia. Jurnal PRofesi Humas.Vol. 2 No. 1, 37-44.

Hikmat, M. M. (2011). Metode penelitian; dalam perspektif ilmu komunikasi dan sastra. Yogyakarta: Graha Ilmu.

Jamali, D. (2008). A stake holder approach to corporate social responsibility: a fresh perspective into theory and practice. Journal of Business Ethics, DOI 10.1007/ s10551-007-9572-4.

Kartini, D. (2009). Corporate social responsibility transformasi konsep sustainability management dan implementasi di indonesia. Bandung: Refika Aditama.

Kotler, P. \& Lee, N. (2005). Corporate social responsibility: doing good for your company and your cause. New Jersey: John Wiley \& Sons, Inc.

Kriyantono, R. (2010). Teknik praktis riset komunikasi: disertai contoh praktis riset media, public relations, advertising, komunikasi organisasi, komunikasi pemasaran. Jakarta: Kencana.

Lako, A. (2011). Dekonstruksi csr dan reformasi paradigma bisnis \& akuntansi. Jakarta: Erlangga.

Moir, L. (2001). What do we mean by corporate social responsibility?. Corporate Governance: The International Journal of Business In Society, Vol. 1 Iss 2 pp. 16 - 22. Nugraha, A. R. (2015). Implementasi kegiatan corporate social responsibility "go green economic" berbasiskan kearifan lokal. Jurnal Komunikasi. Vol. 7, No. 2, 118-128.

Nurjanah. (2013). Pengelolaan corporate social responsibility dalam membangun citra perusahaan. Jurnal Ilmu Komunikasi. Vol. 2, No. 2, 73-82.

Rajasekhara M. P. Y. B. K. M. (2010). Corporate social responsibility: a study of kazakhstan corporate sector. Social Responsibility Journal, Vol. 6 Iss 1 pp. 33 - 44.

Sugiyono. (2010). Metode penelitian administrasi dilengkapi dengan metode $r \& d$. Bandung: Penerbit Alfabeta.

Sutojo, S. (2004). Membangun citra perusahaan. Jakarta: Damar Mulia Pustaka.

Walhi. (2014). Tercabutnya Hak Atas Jaminan Lingkungan yang Baik dan Sehat dalam Kehidupan Masyarakat. Diakses dari http:// walhi.or.id/2014/23/tercabutnya-hak-atasjaminan-lingkungan-yang-baik-dan-sehatdalam-kehidupan-masyarakat.html. 